\title{
Length Weight Relationship and Condition Factor of Cultured Rainbow Trout, Oncorhynchus mykiss (Walabum, 1792)
}

\author{
Ishtiyaq Ahmad and Imtiaz Ahmed* \\ DST Sponsored Fish Nutrition Laboratory, Department of Zoology, University of Kashmir, Hazratbal, \\ Srinagar-190006, India; imtiazamu1@yahoo.com
}

\begin{abstract}
A Length Weight Relationship (LWR) and condition factor of cultured rainbow trout Oncorhynchus mykiss was studied. A total of 144 specimens were used obtained from National fish farm Laribal, Dachigam during January 2017 to December 2018. The coefficient ' $b$ ' value of LWR showed negative allometric $(b<3)$ growth throughout the year except in the months of October and December, where the positive allometric growth pattern was reported $(b>3)$. In order to generate more precise information, a trend line graph was draw to compare condition of fish in different months, which indicated declining growth pattern condition. The condition factor showed an overt variation with highest value was reported during the breeding season. The result obtained in this study will be useful for the improvement of production and quality of trout under cultured condition.
\end{abstract}

Keywords: Condition Factor, Dachigam, Length Weight Relationship, Oncorhynchus mykiss

\section{Introduction}

Trout farming has much more popularity in the Kashmir valley, because different farmers wish to increase overall production in the state. Kashmir Himalaya is very famous for trout. Both brown and rainbow species are a cold water fish found aplenty in the Rivers flowing through Jammu and Kashmir from the upper reaches of Himalayan region. Trout, a highly nutritious fish, is said to have been introduced in the Kashmir valley by the British Empire for angling during British rule. The J and $\mathrm{K}$ fisheries department was established trout culture raceways on the outskirts of Srinagar called as Dachigam fish farm, where trout's are being cultured ${ }^{10}$. Although the station has produced a good production of trout, but still have a scope to increase production as there is a decline in production was reported during the last few years. Therefore to check the well being of the fish, a LWR study was conducted.

Length-weight relationships are considered basic and regular objectives in fisheries research and provide useful information for fishery managers ${ }^{13,18}$. LWRs are also useful for life histology and morphological comparisons among species and populations ${ }^{12}$. The growth rate is an important parameter that influences population dynamics in fishes ${ }^{16,17}$. It is a good indicator of the health of individuals and populations. Apart from length-weight relationship, the condition factor $(K)$ is equally important in fisheries, because it allows the estimation of average weight of the fish of a given length group by establishing a mathematical relation between them ${ }^{15,11}$.

The aim of the present study was to estimate the LWRs and condition factor for O. mykiss collected from National Fish Seed Farm Laribal, Dachigam, Kashmir.

\section{Materials and Methods}

\subsection{Study Site and Collection of Fish for} Measurement of Length Weight Relationship (LWR) Samples of O. mykiss were collected from National Fish Seed Farm Laribal, Dachigam, Srinagar, India. The study was conducted on monthly basis from January 2017-December 2018. After collection, the samples were brought to laboratory and measurement of length and weight of each individual were taken by using digital vernier caliper and digital top loading balance (Schimadzu UX320G). The total length of fish was

${ }^{*}$ Author for correspondence 
measured to its nearest $0.01 \mathrm{~cm}$ and total body weight was measured to its nearest $0.01 \mathrm{~g}$ as per standard procedure. The total length of fish was taken from the tip of snout to the extended tip of the caudal fin. The relationship between length and weight of fish was analyzed by measuring length and weight of fish specimen collected from study area. The statistical relationship between these parameters of fishes worked out by using algometric equation as per Froese ${ }^{5}$.

$\mathrm{W}=\mathrm{aLb}$.

Where $\mathrm{W}=$ total weight $(\mathrm{g})$.

$\mathrm{L}=$ length of fish $(\mathrm{cm})$.

$\mathrm{a}=$ Initial growth coefficient

$\mathrm{b}=$ slope or the growth coefficient.

The value of constants ' $a$ ' and 'b' was estimated by linear regression after logarithmic transformation of weight and length data by using formula:

$$
\log W=\log a+b \log L
$$

\subsection{Condition Factor $(\mathrm{K})$}

The condition factor is used for comparing the condition, fatness or well being of fish, based on the assumption that heavier fish of a given length are in better condition. The coefficient of condition ' $K$ ' was calculated by using Fulton', equation.

$$
\mathrm{K}=\mathrm{W} / \mathrm{L}^{3} \mathrm{x} 100
$$

Where, $\mathrm{W}=$ weight in grams, $\mathrm{L}=$ length in $\mathrm{cm}$, and 100 is a factor to bring the value of $\mathrm{K}$ near unity Froese $\mathrm{s}^{5}$.

\section{Results}

\subsection{Length Weight Relationship (LWR)}

A total of 144 specimens were utilized for this purpose. Significance difference between the regression coefficient was noted. The length range of fish was $24.4-35.2 \mathrm{~cm}$ and total weight 198-450 g. The regression equation for Length Weight Relationship (LWR), coefficient of determination $\left(\mathrm{r}^{2}\right)$, growth coefficient (b) is given in (Table 1). In the present study, the LWR and condition factor $(\mathrm{K})$ of $O$. mykiss showed significant variation among these parameters. The regression graph of O. mykiss is depicted in (Figure 1). The combined regression was expressed as $\mathrm{Y}=1.364 \mathrm{x}+0.492$ with $\mathrm{r}^{2}$ highly significant $r^{2}$ value $(0.399)$. The value of ' $b$ ' showed deviation from cube law throughout the year except in the months of October and December, where 'b' was recorded to as greater than 3 and which indicate that the growth of the fish assumed positive allometric. Whereas, for rest of the months, a negative allometric growth was observed as 'b' was estimated less than 3 . The growth coefficient was minimum in the month of January $(b=0.077)$ and maximum values of growth coefficient were obtained in the months of October and December $(b>3)$.

\subsection{Condition Factor $(\mathrm{K})$}

Condition of fish in general is an expression of relative fatness of fish. The monthly variation of condition factor of $O$. mykiss was calculated and results are presented in (Table 1 and Figure 2). The monthly variation and fluctuation in ' $\mathrm{K}$ ' factor was in the range of $0.98-1.58$. The highest value of ' $K$ ' was reported in the month of January followed by February, April and July. While

Table 1. Descriptive statistics and estimated parameters of Length Weight Relationships and condition factor (K) of $O . m y k i s s$ from

\begin{tabular}{|c|c|c|c|c|c|c|c|c|c|}
\hline \multirow[b]{2}{*}{ Months } & \multirow[b]{2}{*}{$\mathbf{N}$} & \multicolumn{2}{|c|}{ Total length $(\mathrm{cm})$} & \multicolumn{2}{|c|}{ Total weight (g) } & \multicolumn{2}{|c|}{ Regression parameters $\mathrm{W}=\mathrm{aL}^{\mathrm{b}}$} & \multirow[b]{2}{*}{$\mathbf{r}^{2}$} & \multirow[b]{2}{*}{$\mathbf{K}$} \\
\hline & & Min. & Max. & Min. & Max. & a & b & & \\
\hline January & 12 & 24.7 & 27.9 & 198 & 262 & 2.263 & 0.077 & 0.038 & 1.58 \\
\hline February & 12 & 25.6 & 28 & 255 & 320 & 1.163 & 0.912 & 0.382 & 1.49 \\
\hline March & 12 & 28.4 & 32 & 235 & 342 & 1.754 & 0.485 & 0.206 & 1.10 \\
\hline April & 12 & 24.7 & 30.9 & 275 & 380 & 0.441 & 1.428 & 0.915 & 1.48 \\
\hline May & 12 & 26.2 & 32.4 & 202 & 291 & 0.054 & 1.616 & 0.826 & 1.08 \\
\hline June & 12 & 25.2 & 32 & 269 & 390 & 1.148 & 0.930 & 0.686 & 1.20 \\
\hline July & 12 & 24.2 & 33.4 & 210 & 415 & 0.241 & 1.565 & 0.785 & 1.42 \\
\hline August & 12 & 26 & 33.6 & 210 & 450 & 1.031 & 2.428 & 0.889 & 1.34 \\
\hline September & 12 & 25.1 & 34.6 & 275 & 395 & 1.056 & 0.981 & 0.871 & 1.26 \\
\hline October & 12 & 28.3 & 32 & 200 & 420 & 2.515 & 3.393 & 0.645 & 1.19 \\
\hline November & 12 & 29.2 & 35.2 & 280 & 356 & 1.297 & 0.799 & 0.741 & 0.98 \\
\hline December & 12 & 27.2 & 31.4 & 205 & 415 & 2.459 & 3.384 & 0.895 & 1.29 \\
\hline
\end{tabular}
National Fish Seed Farm, Laribal, Dachigam

Total number of samples; a, intercept; b, slope; r, regression coefficient; K, condition factor. 


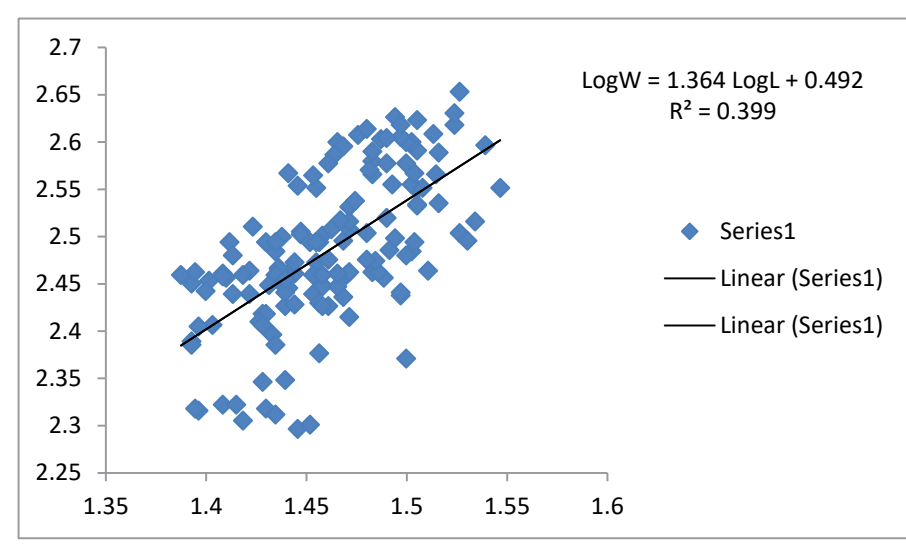

Figure 1. Showing combined regression graph of Length Weight Relationship of O. mykiss.

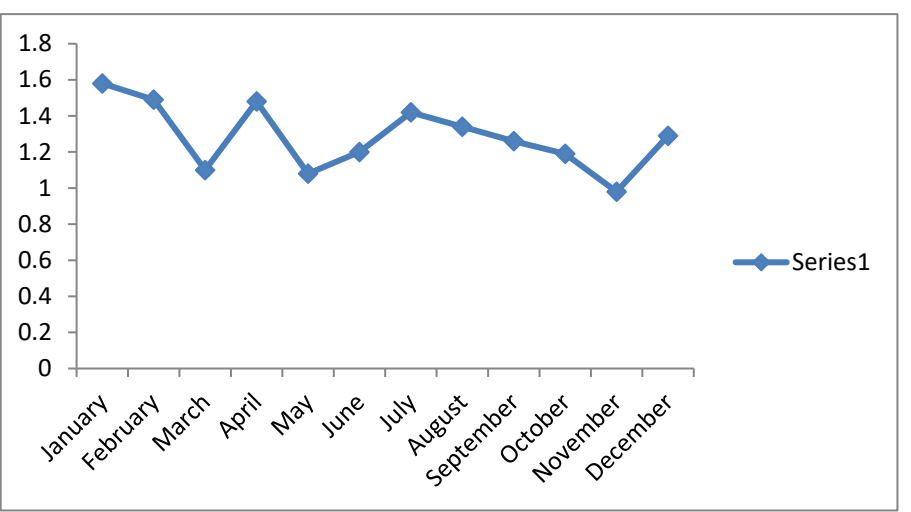

Figure 2. Month-wise variation in condition factor of O. mykiss collected from National fish seed farm Laribal, Dachigam.

lowest value of condition factor was recorded in the month of January.

\section{Discussion}

It is obvious that growth of fishes or any other animal increases with body length, thus it proves that length and weight are directly interrelated. The weight of the fish increased logarithmically with an increase in length, with the value lying between 2.5 and 3.5, but usually close to $3.0^{2}$. The Length Weight Relationship (LWR) can be indicative of spatial and temporal variations related to certain environmental factors such as food competition, overfishing and different trophic potential of the rivers water temperature ${ }^{7,8}$ and also due to water temperature, food availability and reproductive activity ${ }^{19}$. Regression parameters 'a' and 'b' are affected by a number of various factors, including sex, gonad maturity, habitat, nutrition, season, health status, environmental conditions such as temperature and salinity, stomach fullness, collection gear, general fish condition and differences in length range of fish specimens ${ }^{5,6}$. Growth is considered isometric when ' $b$ ' value is equal to 3 or allometric if otherwise (positive allometric if $b>3$ and negative allometric if $\mathrm{b}<3$ ). In the present study, the values of ' $b$ ' for the Length Weight Relationship were found to show negative allometry for ten months (January, February, March, April, May, June, July, August, September and November) and positive allometry for October and December months selected for analysis of Length Weight Relationship in the fish farm Laribal, Dachigam, Kashmir (Table 1). Similar studies were recorded by Luther ${ }^{9}$ and Sharma and Bhat ${ }^{18}$ for Mugil cephalus and rainbow trout respectively. This indicates that the fish grows at different rate from the rest of the body.

The condition factor of $O$. mykiss showed variation in different months and were observed to be in good condition, as the ' $\mathrm{K}$ ' values were greater than 1 (1.08-1.58) except in November (0.098). During the months of January, February, April and July, ' $K$ ' was higher when fish entered into the maturation phase and for rest of the months ' $\mathrm{K}$ ' showed slightly lower values (Figure 2). However, the results of this study are in conformity to those reported by Rabe ${ }^{14}$, where the value of condition factor is between 0.859 and 1.104 for rainbow trout in Alpine lakes. Moreover, Cade et al. (1987) reported the ' $\mathrm{K}$ ' value $0.82-1.17$ for rainbow trout collected from southern Appalachian streams. The variation in condition factors among the fish due to many factors such as environmental factors, parasitism and food supply have great influence on the health of the fish ${ }^{9}$. The seasonal difference in condition factors could also be attributed to low feeding intensity and degeneration of ovaries during winter and high feeding intensity and full development of gonads during summer months. Besides that during winters, the high values of ' $K$ ' could also be attributed to high deposition of fats as preparation for the coming breeding season. From a nutritional point of view, increase in ' $\mathrm{K}$ ' value indicates the accumulation of fat and sometimes gonadal development. Figueiredo-Garutin and Garuti ${ }^{4}$ stated that the lowest ' $K$ ' value occurs in the beginning of the reproductive period and the highest at its end.

Limited work has been carried out so far on O. mykiss from National Fish Seed Farm Laribal, Dachigam. So, in the present study an attempt has been made to provide information about the growth condition of $O$. mykiss from cultured habitat. This study will enlighten biologists about the status and growth condition of this fish and will be useful for the fishery biologists and conservation agencies, for successful development, management and production.

\section{Ethical Approval}

Not required as per the guidelines of Committee for the Purpose of Control and Supervision of Experiments on Animals (CPCSEA). 


\section{Conflict of Interest}

The authors declare that they have no conflict of interest.

\section{Acknowledgements}

The authors are grateful to the Head, Department of Zoology, University of Kashmir, Hazratbal, Srinagar, India for providing the laboratory facilities and gratefully acknowledge the financal support from the Department of Biotechnology (DBT), Govt of India, New Delhi on Fish Nutrition and Diet development programme.

\section{References}

1. Cada GF, Loar JM, Sale MJ. Evidence of food limitation of rainbow and brown trout in southern appalachian soft-water streams, Trans Am Fish Soc. 1987; 116:692-702. https://doi. org/10.1577/1548-8659(1987)116<692:EOFLOR>2.0.CO;2

2. Carlander KD. Handbook of freshwater fishery biology. Dubuque, Iowa: William C. Brown; 1950.

3. FAO. The state of world fisheries and aquaculture. Contributing to food security and nutrition for all. 2012. p. 24.

4. Figueiredo-Garuti ML, Garuti V. Total condition factor and somatic condition factor for females astyanax bimaculatus (Pisces, Characidae) coming from the Northwest Region of Sao Paulo, Parana River Basin. IX Brazilian Meeting of Ichthyology. 1991. p. 62.

5. Froese R. Cube law, condition factor and Weight Length Relationship: History, meta-analysis and recommendations. J Appl Ichthyol. 2006; 22:241-53. https://doi.org/10.1111/j.14390426.2006.00805.x

6. Fulton TW. The rate of growth of fishes. Twenty Second Annual Report Part III. Fish. Board Scot. Edinb. 1904. p. 141-241.
7. Kleanthids PK, Sinis AI, Stergiou KI. Length Weight Relationships of freshwater fishes in Greece. Naga, ICLARM Q. 1999; 22:37-41.

8. LeCren ED. The Length Weight Relationship and seasonal cycle in gonad weight and condition in the Perch (Perca fluviatilis). J Anim Ecol. 1951; 20:201-19. https://doi.org/10.2307/1540

9. Luther G. Some observations on the biology of Liza macrolepis (Smith) and Mugil cephalus Linnaeus (Mugilidae) with notes on the fishery of grey mullets near Mandapam. Indian J Fish. 1968; 10:642-66.

10. Manager F. Laribal Trout Fish Farm Data Book. 2017.

11. Mir JI, Sarkar UK, Dwivedi AK,Gusain OP, Pal A and Jena JK. Pattern of intra basin variation in condition factor, relative condition factor and form factor of an Indian Major Carp, Labeo Rohita (Hamilton-Buchanan, 1822) in the Ganges Basin, India. Europ J Biol Sci. 2012; 4:126-35.

12. Petraiks G, Stergiou KI. Weight Length Relationships for 33 fish species in Greek waters. Fish Res. 1995; 21:465-9. https://doi. org/10.1016/0165-7836(94)00294-7

13. Pitcher TJ, Hart PJ. Fisheries ecology. London: Chapman and Hall; 1982

14. Rabe FW. Seasonal age distributions and maturity stage in a naturalized rainbow trout (Oncorhynchus mykiss Walbaum) population in southern Chile reveal an ad-fluvial life history. Northwest Sci. 1967; 41:12-22.

15. Sarkar UK, Deepak PK, Negi RS. Length Weight Relationship of clown knife fish Chitala chitala (Hamilton 1822) from the Ganga Basin, India. J Appl Ichthyol. 2008; 25:232-3. https://doi. org/10.1111/j.1439-0426.2008.01206.x

16. Seshappa G. Recent studies on age determination of Indian fishes using scale, otolith and other hard parts. Indian J Fish. 1999; 46:1-11.

17. Shamsan EF, Ansari ZA. Study of age and growth of Indian sand whiting, Sillago Sihama (Forsskal) from Zuari Estuary, Goa. Indian J Mar Sci. 2010; 39:1-5.

18. Sharma RK, Bhat RA. Length Weight Relationship, condition factor of rainbow trout (Oncorhynchus mykiss) from Kashmir waters. Annals of Biological Research. 2015; 6:25-9.

19. Wootton RJ. Ecology of teleost fishes. London: Chapman and Hall; 1990. 